\title{
Comparison of the Nitrification Efficiencies of Three Biofilter Media in a Freshwater System
}

\author{
Dicky Harwanto ${ }^{1,2}$, Sung-Yong $\mathrm{Oh}^{3}$ and Jae-Yoon $\mathrm{Jo}^{1,4 *}$ \\ ${ }^{1}$ Department of Fisheries Biology, Pukyong National University, Busan 608-737, Korea \\ ${ }^{2}$ Department of Fisheries and Marine Science, Diponegoro University, Semarang 50275, Indonesia \\ ${ }^{3}$ Marine Biology and Living Resources Research Department, Korea Ocean Research and Development Institute, Seoul 425-600, Korea \\ ${ }^{4}$ Tianjin Agricultural University, No. 22, Jinjing Road, Xiqing District Tianjin, 300384, P.R. China
}

\begin{abstract}
Total ammonia nitrogen (TAN) removal efficiencies of a sand filter (SF), polystyrene microbead filter (PF), and Kaldnes bead filter (KF) media were evaluated under ammonia loading rates of 5, 25, and $50 \mathrm{~g} \mathrm{~m}^{-3}$ day ${ }^{-1}$ The volume of each filter media tested was $7 \mathrm{~L}$, and the water flow rate for all filter media was $24 \mathrm{~L} / \mathrm{min}$. The specific surface areas of the SF, PF, and KF were 7,836, 3,287, and $500 \mathrm{~m}^{2} / \mathrm{m}^{3}$, respectively. Sand was fluidized and the other two media were trickle filtered. The volumetric TAN removal rate increased with increasing ammonia loading rate for all filter media. Mean volumetric TAN removal rates under the ammonia loading rates of 5,25 , and $50 \mathrm{~g} \mathrm{~m}^{-3}$ day $^{-1}$ in $\mathrm{SF}\left(39.3,168.6\right.$, and $322.7 \mathrm{~g} \mathrm{~m}^{-3}$ day $^{-1}$, respectively) were higher than those in PF (35.0, 157.4 , and $310.5 \mathrm{~g} \mathrm{~m}^{-3}$ day $^{-1}$, respectively) and KF $\left(32.1,142.5\right.$, and $288.1 \mathrm{~g} \mathrm{~m}^{-3}$ day $^{-1}$, respectively). These results were related to differences in the specific surface areas of the filter media. PF was the most economic media for efficiently removing TAN.
\end{abstract}

Key words: Recirculation system, Biofilter media, Nitrification, Freshwater, Ammonia removal

\section{Introduction}

Many studies have been conducted to obtain biofilter performance data for maintaining good water quality in a recirculating system. Each type of biofilter has advantages and disadvantages (Wheaton et al., 1994a). Although various types of biofilter media are in use, efforts to identify the most effective, economic, and efficient media are ongoing. Sand (Wheaton et al., 1994b; Shnel et al., 2002; Summerfelt, 2006), polystyrene microbeads (Greiner and Timmons, 1998; Malone and Beecher, 2000; Malone and Pfeiffer, 2006; Timmons et al., 2006), and artificial plastic (Eikebrokk, 1990; Eikebrokk and Ulgenes, 1998; Rusten et al., 2006) have become important biofilter media.

Limited data are available about biofilter nitrification performance and maintaining water quality considering total media volume. Media volume becomes important when con- sidering the specific surface area (SSA) and biofilter space (Wheaton et al., 1994a; Lekang and Kleppe, 2000). Media with different SSAs produce different surface areas in the same volume. Media with a lower SSA require higher volume and biofilter space to obtain the same surface area as a media with a high SSA. Hence, comparison of the performances of different biofilter media at the same volume is needed.

Sand is the most well-known natural media and has been used successfully (Wheaton et al., 1994b, Losordo et al., 1998; Shnel et al., 2002; Summerfelt, 2006). Among artificial media, polystyrene has widespread commercial use (Greinner and Timmons, 1998; Malone and Beecher, 2000; Malone and Pfeiffer, 2006; Timmons et al., 2006), and Kaldnes medium is a recently developed artificial plastic medium (Lekang and Kleppe, 2000; Rusten et al., 2006). The objective of this study
Open Access http://dx.doi.org/10.5657/FAS.2011.0363

This is an Open Access article distributed under the terms of the Creative Commons Attribution Non-Commercial License (http://creativecommons. org/licenses/by-nc/3.0/) which permits unrestricted non-commercial use, distribution, and reproduction in any medium, provided the original work is properly cited. pISSN: 2234-1749 eISSN: 2234-1757
Received 1 September 2011; $\quad$ Revised 21 October 2011; Accepted 9 November 2011

*Corresponding Author

E-mail: jyjo@pknu.ac.kr 


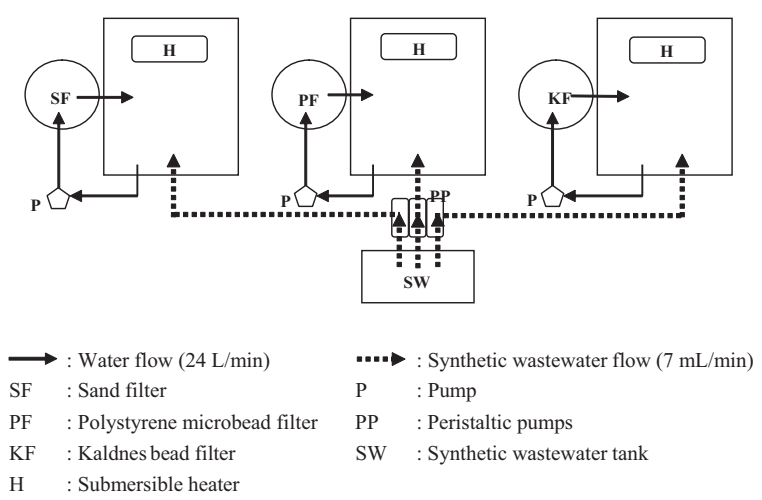

Fig. 1. Schematic diagram of recirculating aquaculture systems used for nitrification efficiency studies of three different biofilter media: SF, PF, and KF.

was to compare total ammonia nitrogen (TAN) removal efficiencies among three biofilter media, i.e., sand (SF), polystyrene microbeads (PF), and Kaldnes beads (KF) under three different ammonia loading rates in fresh water. We also considered the cost of each medium.

\section{Materials and Methods}

\section{System design}

The experiments were conducted in three closed recirculating system units. Each system consisted of one aquarium (width, $45 \mathrm{~cm}$; length, $60 \mathrm{~cm}$; diameter, $45 \mathrm{~cm}$ ), one biofilter cylinder (diameter, $19 \mathrm{~cm}$; length, $100 \mathrm{~cm}$ ), and one pump (Fig. 1). The total water volume used in each system was 100 $\mathrm{L}$. Water from the aquarium was pumped into a biofilter cylinder and then flowed back to the aquarium.

A $40 \mathrm{~L}$ synthetic wastewater tank was installed and three peristaltic pumps (Cheon Sei, Korea) were employed to distribute synthetic wastewater $(7 \mathrm{~mL} / \mathrm{min})$ into each of the biofilters. The composition of the synthetic wastewater used in this study is shown in Table 1. A submersible heater was used in each system to maintain temperature at $22-26^{\circ} \mathrm{C}$.

The three biofilter media (SF, PF, and $\mathrm{KF}$ ) were installed

Table 1. Composition and amount of chemicals (g) used for making 40 L of synthetic wastewater (modified from Roger and Klementson, 1985)

\begin{tabular}{|c|c|c|c|}
\hline Composition & Treatment $1(\mathrm{~g})^{*}$ & Treatment $2(\mathrm{~g})^{\dagger}$ & Treatment $3(\mathrm{~g})$ \\
\hline$\left(\mathrm{NH}_{4}\right)_{2} \mathrm{SO}_{4}$ & 9.428 & 47.140 & 94.280 \\
\hline $\mathrm{NaHCO}_{3}$ & 12.096 & 60.478 & 120.956 \\
\hline $\mathrm{Na}_{2} \mathrm{HPO}_{4}$ & 3.116 & 15.578 & 31.156 \\
\hline Glucose & 2.441 & 12.207 & 24.414 \\
\hline $\mathrm{MnSO}_{4}$ & 0.151 & 0.757 & 1.514 \\
\hline
\end{tabular}

"Ammonia loading rate is $5 \mathrm{~g} \mathrm{~m}^{-3} \mathrm{~d}^{-1},{ }^{\dagger}$ Ammonia loading rate is $25 \mathrm{~g} \mathrm{~m}^{-3} \mathrm{~d}^{-1}$, ${ }^{\ddagger}$ Ammonia loading rate is $50 \mathrm{~g} \mathrm{~m}^{-3} \mathrm{~d}^{-1}$. separately in $7 \mathrm{~L}$ filter cylinders. The sand filter was up-flow filtered to fluidize the sand, and the other two were filtered by down-flow movement. The SSAs of the SF, PF, and KF media were $7,836,3,287$, and $500 \mathrm{~m}^{2} / \mathrm{m}^{3}$, respectively.

\section{Ammonia loading rate}

Three ammonia loading rates of 5,25 , and $50 \mathrm{~g} / \mathrm{m}^{3}$ water per day were applied as treatments 1,2 , and 3, respectively. These ammonia loading rates were based on the ammonia excretion rates of Nile tilapia fingerlings $(\mathrm{Oh}, 2001)$ and equivalent to tilapia biomasses of 5,25 , and $50 \mathrm{~kg} / \mathrm{m}^{3}$ water. The synthetic wastewater was moved with peristaltic pumps, which were adjusted to $7 \mathrm{~mL} / \mathrm{min}$ for each filter system. This adjustment provided $10 \mathrm{~L}$ of synthetic wastewater daily to each biofilter system. The flow rates through the biofilters were adjusted to $24 \mathrm{~L} / \mathrm{min}$.

\section{Preparation of biofilter conditioning}

Activated sludge was taken from the biofilter of a closed recirculating aquaculture system, the Intensive Bio-Production Korea system, at the Fish Culture Station Center, Pukyong National University, Korea, and cultured in a tank with a synthetic wastewater loading rate of $200 \mathrm{mg} \mathrm{L}^{-1}$ day $^{-1}$ for 2 weeks.

When the nitrifying bacteria were inoculated into the experimental biofilters, the mixed liquid suspended solid concentration of bacteria was $4,510 \mathrm{mg} / \mathrm{L}$. Bacteria were cultured continuously in the synthetic wastewater with an ammonia loading rate of $50 \mathrm{~g} \mathrm{~m}^{-3} \mathrm{day}^{-1}$ for 3 weeks. When nitrification had stabilized, water from each system was changed with aged groundwater of the same temperature, and the experiment was started.

Concentrations of TAN, nitrite-nitrogen $\left(\mathrm{NO}_{2}-\mathrm{N}\right)$, and nitrate nitrogen $\left(\mathrm{NO}_{3}-\mathrm{N}\right)$ were monitored daily to assess establishment of nitrifiers and their activity. The acclimated condition for each biofilter was determined when TAN and $\mathrm{NO}_{2}-\mathrm{N}$ concentrations of the inlet and outlet water for each biofilter system were maintained at constant concentrations. Biofilter performance experiments were initiated following this acclimation. Before changing the ammonia loading rate, water from all systems was exchanged with new aged groundwater, and the acclimation process was repeated.

\section{Water sampling}

Water samples were collected daily and measured in situ to monitor removal of nitrogenous compounds. Samples were taken from three sampling points in each biofilter system, i.e., from the aquarium and from the inlet and outlet of the biofilter. These samples were analyzed for TAN, $\mathrm{NO}_{2}-\mathrm{N}$, and $\mathrm{NO}_{3}-$ $\mathrm{N}$. Other parameters, including water temperature, dissolved oxygen (DO), and $\mathrm{pH}$ were measured daily in the aquarium. Ammonia removal efficiency data were collected when TAN 
concentrations in all biofilter systems decreased sharply during the acclimation period.

Equal volumes of synthetic wastewater (10 L/day) were added to each biofilter system continuously for 24 hours using the peristaltic pumps. Consequently, $10 \mathrm{~L}$ of water from each biofilter system was removed daily to maintain total water volume in each system.

\section{Water quality measurement methods}

TAN concentration was measured with an ORION ammonia meter (Model 720 A, USA). Ion chromatography was used to measure $\mathrm{NO}_{2}$ and $\mathrm{NO}_{3}$ concentrations. Water temperature and DO were determined using OxyGuard. A Pin Point $\mathrm{pH}$ Monitor from American Marine Inc. was used to determine $\mathrm{pH}$.

Volumetric ammonia removal rates (VAR, $\left.\mathrm{g} \mathrm{m}^{-3} \mathrm{day}^{-1}\right)$ and areal ammonia removal rates (AAR, $\mathrm{g} \mathrm{m}^{-2} \mathrm{~d}^{-1}$ ) were calculated by the following equation:

$\mathrm{VAR}=\left(\mathrm{TAN}_{\text {in }}-\mathrm{TAN}_{\text {out }}\right) \times \mathrm{Q} \times \mathrm{V}^{-1}(\mathrm{Oh}, 2001)$

AAR $=\left(\right.$ TAN $_{\text {in }}-$ TAN $\left._{\text {out }}\right) \times \mathrm{Q} \times \mathrm{V}^{-1} \times \mathrm{S}^{-1}($ Kamstra et al., 1998)

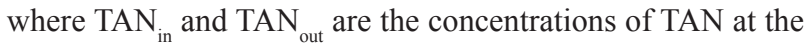
inlet and outlet of the biofilter $\left(\mathrm{g} / \mathrm{m}^{3}\right)$, respectively, $\mathrm{Q}$ is the total water flow through the filter $\left(\mathrm{m}^{3} / \mathrm{day}\right), \mathrm{V}$ is the volume of the filter bed $\left(\mathrm{m}^{3}\right)$, and $\mathrm{S}$ is the SSA of the medium $\left(\mathrm{m}^{2} / \mathrm{m}^{3}\right)$

\section{Statistical analysis}

All statistical analyses were performed using the Minitab statistical software package release version 11.12 (Minitab, Inc., State College, PA, USA). The concentrations of ammonia and ammonia removal rates in each biofilter system were compared using a one-way analysis of variance. The differences between ammonia concentration and ammonia removal rate were analyzed using Tukey's HSD test, with $P<0.05$ considered significant.

\section{Results}

\section{Experimental conditions}

Temperatures in $\mathrm{SF}, \mathrm{PF}$, and $\mathrm{KF}$ remained in the range of 22.4-25. $6^{\circ} \mathrm{C}$, and the $\mathrm{pH}$ level remained in the range of 6.65 7.38 during the study period. DO levels in the biofilters ranged from 6.7 to $9.1 \mathrm{mg} / \mathrm{L}$.

\section{Biofilter conditioning}

The conditioning process for each treatment (ammonia loading rates of 5,25 , and $50 \mathrm{~g} \mathrm{~m}^{-3} \mathrm{~d}^{-1}$ ) was started in all three biofilter systems at the same time. The ammonia loading rate
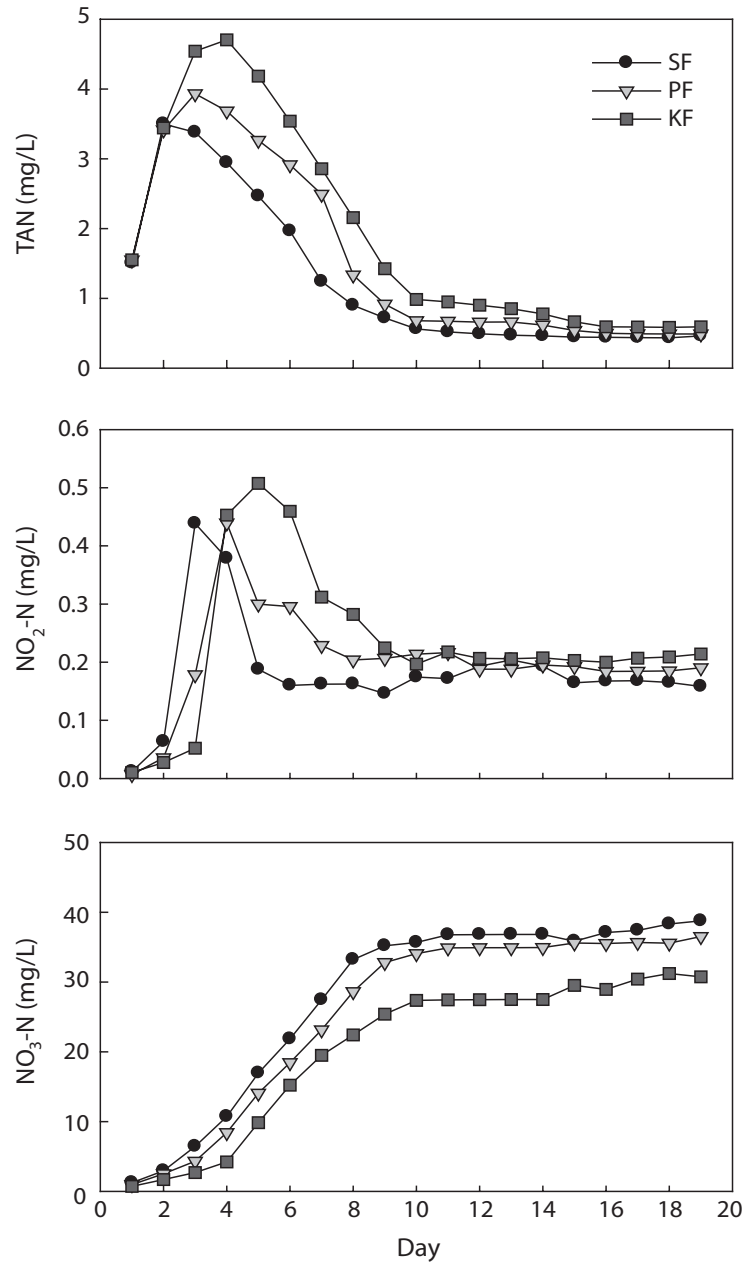

Fig. 2. Changes of total ammonia nitrogen (TAN), nitrite nitrogen $\left(\mathrm{NO}_{2}-\mathrm{N}\right)$, and nitrate nitrogen $\left(\mathrm{NO}_{3}-\mathrm{N}\right)$ in sand filter (SF), polystyrene microbead filter (PF), and Kaldnes bead filter (KF) under ammonia loading rate of $5 \mathrm{~g} \mathrm{~m}^{-3}$ day $^{-1}$.

was maintained at the same amount for each biofilter system throughout the entire period of conditioning and the experiment.

In treatment 1 (ammonia loading rate of $5 \mathrm{~g} \mathrm{~m}^{-3} \mathrm{day}^{-1}$ ), TAN concentrations in $\mathrm{SF}, \mathrm{PF}$, and $\mathrm{KF}$ reached their peaks on days 2,3 , and 4 , respectively, after the experiment had started, and the peak concentrations were $3.5,3.9$, and $4.7 \mathrm{mg} / \mathrm{L}$, respectively (Fig. 2). Following the TAN peak, the ammonia concentrations in SF, PF, and KF decreased gradually and reached $<1$ $\mathrm{mg} / \mathrm{L}$ on days 8,9 , and 10 , respectively. When the TAN level entered the steady state condition, the concentration of TAN remained $<1 \mathrm{mg} / \mathrm{L}$ until the end of the experiment.

The $\mathrm{NO}_{2}-\mathrm{N}$ concentrations in all biofilter systems on day 1 were almost $0 \mathrm{mg} / \mathrm{L}$. However, the concentrations increased sharply the next day and reached their highest levels in SF, PF, and $\mathrm{KF}$ on days 3, 4, and 5, respectively, with concentrations of $0.44,0.44$, and $0.51 \mathrm{mg} / \mathrm{L}$. Then, $\mathrm{NO}_{2}-\mathrm{N}$ concentrations de- 

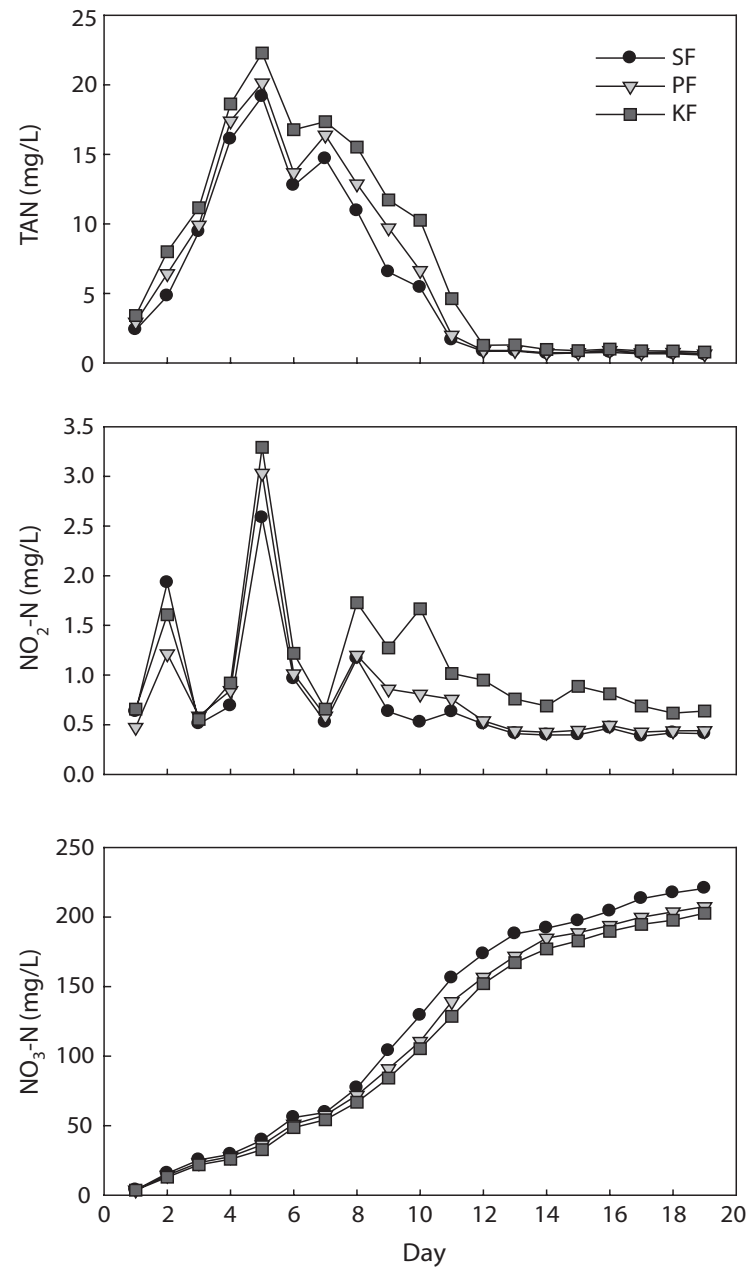

Fig. 3. Changes of total ammonia nitrogen (TAN), nitrite nitrogen $\left(\mathrm{NO}_{2}-\mathrm{N}\right)$, and nitrate nitrogen $\left(\mathrm{NO}_{3}-\mathrm{N}\right)$ in sand filter (SF), polystyrene microbead filter (PF), and Kaldnes bead filter (KF) under ammonia loading rate of $25 \mathrm{~g} \mathrm{~m}^{-3} \mathrm{day}^{-1}$.

creased gradually and were in a steady state at approximately $0.2 \mathrm{mg} / \mathrm{L}$. When TAN concentration entered the steady state, the $\mathrm{NO}_{2}-\mathrm{N}$ concentrations also entered the steady state.

$\mathrm{NO}_{3}-\mathrm{N}$ concentrations in $\mathrm{SF}, \mathrm{PF}$, and $\mathrm{KF}$ increased continuously from day 2 of the experiment. After TAN entered a steady state, the $\mathrm{NO}_{3}-\mathrm{N}$ concentrations in all biofilters did not increase as fast as before. The highest concentrations of $\mathrm{NO}_{3}-\mathrm{N}$ in $\mathrm{SF}, \mathrm{PF}$, and $\mathrm{KF}$ reached $38.8,36.5$, and $30.8 \mathrm{mg} / \mathrm{L}$, respectively, at the end of the experimental period.

In treatment 2 (ammonia loading rate of $25 \mathrm{~g} \mathrm{~m}^{-3} \mathrm{day}^{-1}$ ), TAN concentrations in SF, PF, and KF peaked on day 5, and the peak concentrations were 19.2, 20.1, and $22.3 \mathrm{mg} / \mathrm{L}$, respectively (Fig. 3). Following the TAN peak, TAN concentrations in $\mathrm{SF}, \mathrm{PF}$, and $\mathrm{KF}$ decreased gradually and reached a steady state at $0.7 \mathrm{mg} / \mathrm{L}$ on day 14 . Steady state TAN concentrations remained until the end of the experiment.

The $\mathrm{NO}_{2}-\mathrm{N}$ concentration in treatment 2 fluctuated during the first 8 days. The concentrations of $\mathrm{NO}_{2}-\mathrm{N}$ in all biofilter systems sharply increased on day 2 but dropped on days 3 and 4 and then reached their highest level on day 5 with concentrations of $2.6,3.0$, and $3.3 \mathrm{mg} / \mathrm{L}$ in $\mathrm{SF}, \mathrm{PF}$, and $\mathrm{KF}$, respectively. After peaking, the $\mathrm{NO}_{2}-\mathrm{N}$ concentrations decreased sharply to $0.6 \mathrm{mg} / \mathrm{L}$ in all biofilters; the concentrations then increased again up to $1.2 \mathrm{mg} / \mathrm{L}$ in both $\mathrm{SF}$ and $\mathrm{PF}$ and $1.7 \mathrm{mg} / \mathrm{L}$ in $\mathrm{KF}$. Subsequently, $\mathrm{NO}_{2}-\mathrm{N}$ concentrations decreased gradually and were in a steady state at approximately $0.4 \mathrm{mg} / \mathrm{L}$ in SF and $\mathrm{PF}$ and at approximately $0.8 \mathrm{mg} / \mathrm{L}$ in $\mathrm{KF}$ on day 13 . When the TAN concentration entered the steady state, the $\mathrm{NO}_{2}-\mathrm{N}$ concentrations had also entered a steady state.

$\mathrm{NO}_{3}-\mathrm{N}$ concentrations in SF, PF, and KF increased continuously up to day 13 of the experiment. After TAN entered a steady state, the $\mathrm{NO}_{3}-\mathrm{N}$ concentrations in all biofilters did not increase as rapidly as before. The highest $\mathrm{NO}_{3}-\mathrm{N}$ concentrations in SF, PF, and KF were 220.6, 207.4, and $202.6 \mathrm{mg} / \mathrm{L}$, respectively, at the end of the experiment.

In treatment 3 (ammonia loading rate $50 \mathrm{~g} \mathrm{~m}^{-3}$ day $^{-1}$ ), TAN concentrations in SF, PF, and $\mathrm{KF}$ all peaked on day 3 at 47.4, 49.2, and $52.2 \mathrm{mg} / \mathrm{L}$, respectively (Fig. 4). Following the TAN peak, the TAN concentrations in SF, PF, and KF decreased gradually and reached a steady state in $\mathrm{SF}$ and $\mathrm{PF}$ at $0.5 \mathrm{mg} / \mathrm{L}$ on day 15 and in $\mathrm{KF}$ at $0.9 \mathrm{mg} / \mathrm{L}$ on day 13 .

Treatment $3 \mathrm{NO}_{2}-\mathrm{N}$ concentrations fluctuated until day 10 . The peak $\mathrm{NO}_{2}-\mathrm{N}$ concentration in SF was reached on day 5 and those in $\mathrm{PF}$ and $\mathrm{KF}$ occurred on day 4, with concentrations of $1.6,6.9$, and $7.9 \mathrm{mg} / \mathrm{L}$, respectively. Subsequently, $\mathrm{NO}_{2}-\mathrm{N}$ concentrations decreased gradually and attained a steady state in SF and $\mathrm{PF}$ at approximately $0.3 \mathrm{mg} / \mathrm{L}$ and in $\mathrm{KF}$ at approximately $0.9 \mathrm{mg} / \mathrm{L}$ on day 13 . When the TAN concentration entered a steady state, the $\mathrm{NO}_{2}-\mathrm{N}$ concentrations also entered a steady state.

The $\mathrm{NO}_{3}-\mathrm{N}$ concentrations in $\mathrm{SF}, \mathrm{PF}$, and $\mathrm{KF}$ increased continuously from day 11. After TAN entered a steady state, the $\mathrm{NO}_{3}-\mathrm{N}$ concentrations in all biofilters did not increase as quickly as before. The highest $\mathrm{NO}_{3}-\mathrm{N}$ concentrations in $\mathrm{SF}$, $\mathrm{PF}$, and KF were 284.3, 280.9, and $253.9 \mathrm{mg} / \mathrm{L}$, respectively, at the end of the experiment.

\section{Biofilter performance}

Significant differences were observed in the volumetric ammonia removal rates among the three biofilters (Fig. 5). The highest volumetric ammonia removal rates were found in SF for all ammonia loading rates of 5, 25, and $50 \mathrm{~g} \mathrm{~m}^{-3} \mathrm{day}^{-1}$, and ammonia removal rates were $39.3,168.6$, and $322.7 \mathrm{~g} \mathrm{~m}^{-3}$ day ${ }^{1}$, respectively. Ammonia removal rates in PF for the 5, 25, and $50 \mathrm{~g} \mathrm{~m}^{-3}$ day $^{-1}$ loading rates were $35.0,157.4$, and $310.5 \mathrm{~g} \mathrm{~m}^{-3}$ day $^{-1}$, respectively, whereas those in KF were 32.1, 142.5, and $288.1 \mathrm{~g} \mathrm{~m}^{-3}$ day $^{-1}$, respectively. The volumetric ammonia removal rates increased with increasing ammonia loading rates in all biofilter systems.

KF showed the highest ammonia removal rate based on 

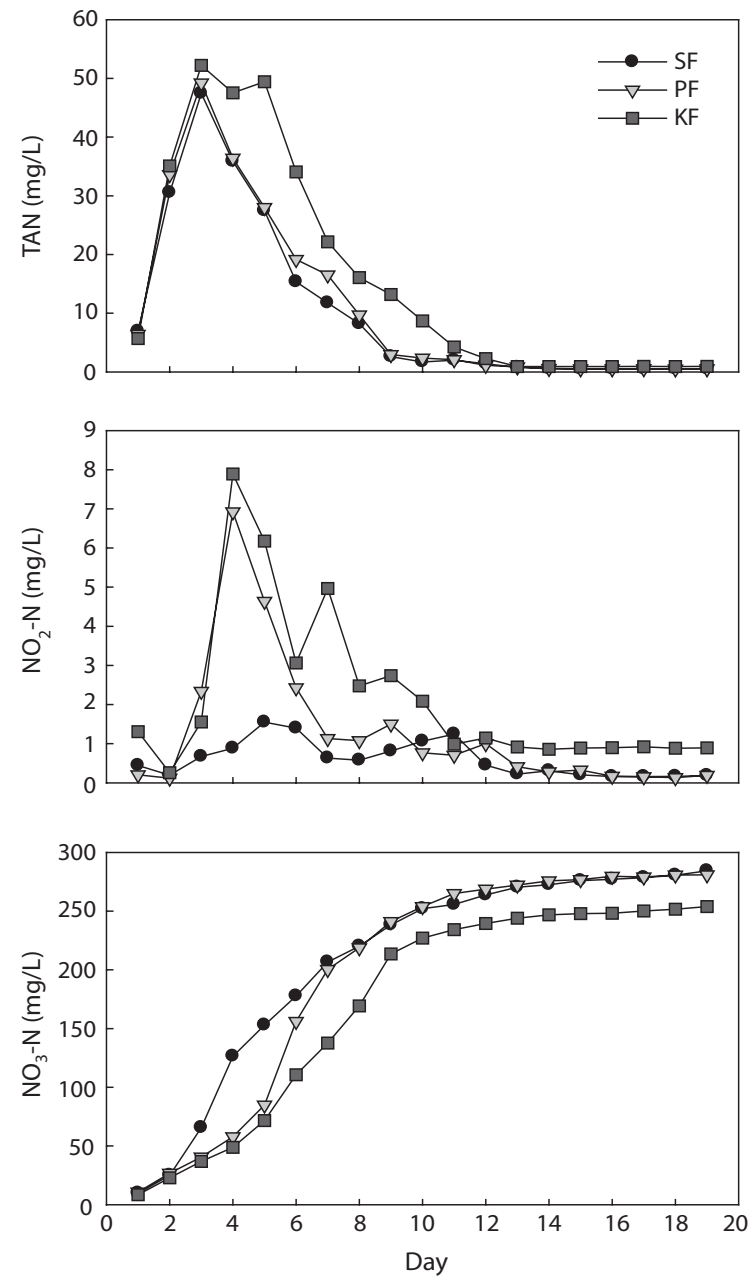

Fig. 4. Changes of total ammonia nitrogen (TAN), nitrite nitrogen $\left(\mathrm{NO}_{2}-\mathrm{N}\right)$, and nitrate nitrogen $\left(\mathrm{NO}_{3}-\mathrm{N}\right)$ in sand filter $(\mathrm{SF})$, polystyrene microbead filter (PF), and Kaldnes bead filter (KF) under ammonia loading rate of $50 \mathrm{~g} \mathrm{~m}^{-3}$ day $^{-1}$.

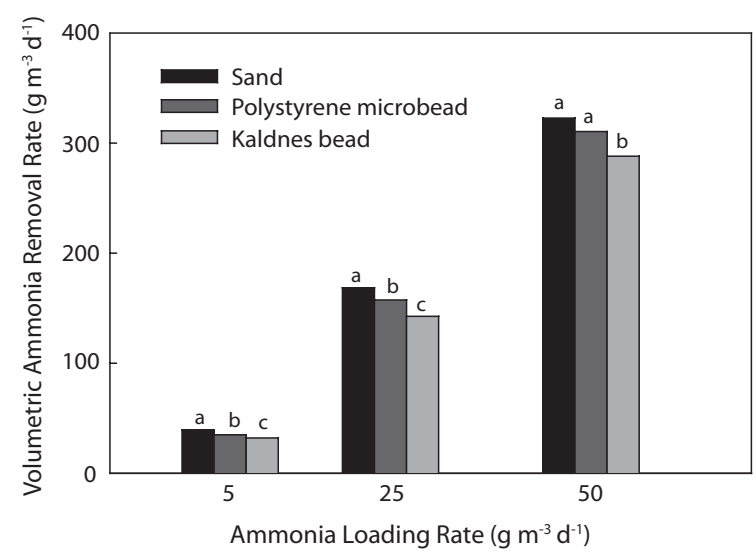

Fig. 5. Comparisons of volumetric ammonia removal rates of three different filter media, sand, polystyrene microbead, and Kaldnes bead filter under three different ammonia loading rates. Different letters on the bars in same ammonia loading rate was significantly different $(P<0.05)$. biofilter area (Fig. 6). The areal ammonia removal rates for $\mathrm{KF}$ under the ammonia loading rates of 5,25 , and $50 \mathrm{~g} \mathrm{~m}^{-3}$ day $^{-1}$ were $64.1,285.1$, and $576.2 \mathrm{mg} \mathrm{m}^{-2}$ day $^{-1}$, respectively, followed by PF $\left(10.6,47.9\right.$, and $94.5 \mathrm{mg} \mathrm{m}^{-2}$ day $^{-1}$, respectively) and SF (5.0, 21.5, and $41.2 \mathrm{mg} \mathrm{m}^{-2}$ day $^{-1}$, respectively). Areal ammonia removal rates also increased with increasing ammonia loading rates in all biofilters.

Similar to the TAN removal efficiencies, $\mathrm{NO}_{2}-\mathrm{N}$ volumetric removal rates under the ammonia loading rates of 5,25 , and $50 \mathrm{~g} \mathrm{~m}^{-3}$ day $^{-1}$ were the highest in SF with actual values of $6.2,8.6$, and $8.6 \mathrm{~g} \mathrm{~m}^{-3} \mathrm{day}^{-1}$, respectively, followed by those in $\mathrm{PF}\left(4.5,7.3\right.$, and $8.0 \mathrm{~g} \mathrm{~m}^{-3}$ day $^{-1}$, respectively). $\mathrm{NO}_{2}-\mathrm{N}$ volumetric removal rates in $\mathrm{KF}$ under the ammonia loading rates of 5, 25, and $50 \mathrm{~g} \mathrm{~m}^{-3}$ day $^{-1}$ were 5.2, 5.6, and $2.4 \mathrm{~g} \mathrm{~m}^{-3}$ day $^{-1}$, respectively.

The $\mathrm{NO}_{3}-\mathrm{N}$ concentrations in $\mathrm{SF}$ at the end of the experiment were the highest among all biofilter systems and all ammonia loading rates. The $\mathrm{NO}_{3}-\mathrm{N}$ concentrations under ammonia loading rates of 5,25 , and $50 \mathrm{~g} \mathrm{~m}^{-3} \mathrm{~d}^{-1}$ were $39.5,224.3$, and $284.3 \mathrm{mg} / \mathrm{L}$, respectively, followed by PF (37.3, 211.0, and $280.9 \mathrm{mg} / \mathrm{L}$, respectively) and $\mathrm{KF}(32.3,205.3$, and 253.9 $\mathrm{mg} / \mathrm{L}$, respectively).

\section{Discussion}

\section{Experimental conditions}

Temperature ranged from $22.4-25.6^{\circ} \mathrm{C}$, DO ranged from 6.7-9.1 $\mathrm{mg} / \mathrm{L}$, and $\mathrm{pH}$ ranged from 6.7-7.4 in all systems under the different ammonia loading rates. These values are in the appropriate ranges for nitrification (Wheaton et al., 1994a). TAN is the most critical water quality parameter in intensive recirculating systems. According to Wheaton et al. (1994a) and Losordo et al. (1998), TAN should be maintained at $<1$

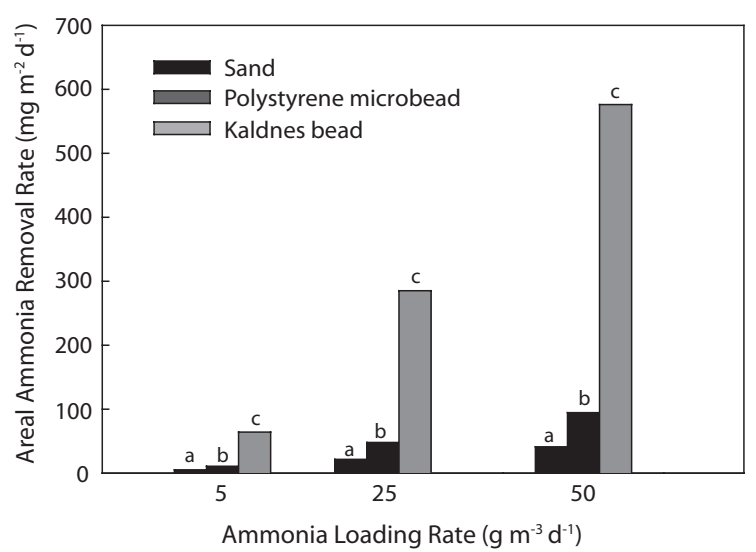

Fig. 6. Comparisons of areal ammonia removal rates of three different filter media, sand, polystyrene microbead, and Kaldnes bead filter under three different ammonia loading rates. Different letters on the bars in same ammonia loading rate was significantly different $(P<0.05)$. 
$\mathrm{mg} / \mathrm{L}$ in intensive recirculating systems. TAN consists of unionized ammonia $\left(\mathrm{NH}_{3}\right)$ and ionized ammonia $\left(\mathrm{NH}_{4}^{+}\right)$, and the former is highly toxic to fish. The proportion of un-ionized TAN is dependent on $\mathrm{pH}$ and water temperature. When water $\mathrm{pH}$ and temperature increase, un-ionized ammonia increases.

\section{Biofilter acclimation}

The TAN concentration in all systems remained at $>1 \mathrm{mg} / \mathrm{L}$ during the acclimation period. However, after the nitrifying bacteria had fully developed (steady-state phase), TAN concentrations in all systems were maintained at $<1 \mathrm{mg} / \mathrm{L} \mathrm{NO}_{2}-$ $\mathrm{N}$, as a product of ammonia oxidation, should be maintained at $<1 \mathrm{mg} / \mathrm{L}$ (Wheaton et al., 1994a; Losordo et al., 1998). Mean concentrations of $\mathrm{NO}_{2}-\mathrm{N}$ were maintained at $<1 \mathrm{mg} / \mathrm{L}$ in all treatments once TAN entered the steady-state phase.

$\mathrm{NO}_{3}-\mathrm{N}$ concentrations were $32.3-284.3 \mathrm{mg} / \mathrm{L}$ in all aquaria with the three different ammonia loading rates at the end of the study. These values are within acceptable limits for aquaculture. Aquatic species can tolerate extremely high levels $(>200$ $\mathrm{mg} / \mathrm{L}$ ) of nitrate-nitrogen in production systems (Losordo et al., 1998). Furthermore, Masser et al. (1999) reported that nitrate, the end product of nitrification, is relatively non-toxic except at very high concentrations $(>300 \mathrm{mg} / \mathrm{L})$.

\section{Biofilter performance}

SF had the best TAN removal rate compared to the other filter media. This was related to the filter media characteristics. Sand media has a very high SSA $\left(7,836 \mathrm{~m}^{2} / \mathrm{m}^{3}\right)$ compared to the SSAs of PF $\left(3,287 \mathrm{~m}^{2} / \mathrm{m}^{3}\right)$ and KF media $\left(500 \mathrm{~m}^{2} / \mathrm{m}^{3}\right)$. The polystyrene microbeads in PF showed better performance than that of the Kaldnes beads in KF. This result was also associated with the SSA. The SSA of PF was higher than that of KF. Malone and Pfeiffer (2006) noted that sand and polystyrene are high SSA media. Wheaton et al. (1994a) stated that the higher SSA of media, the more bacteria can grow per unit volume of media, and the total ammonia removal per unit volume of filter will also be higher. Furthermore, Lekang and Kleppe (2000) reported that filter media with higher SSAs provide larger surface areas for bacterial growth. TAN concentrations in all systems should be maintained under the limit of $<1$ $\mathrm{mg} / \mathrm{L}$. The studied systems maintained TAN concentrations at $<1 \mathrm{mg} / \mathrm{L}$, indicating good performance by all three biofilters.

TAN volumetric removal rates in SF in the present study were 39.3-322.7 $\mathrm{g} \mathrm{m}^{-3}$ day $^{-1}$, which were lower than those in the study of Shnel et al. (2002). The volumetric removal rates in their study were $624.0-1,560.0 \mathrm{~g} \mathrm{~m}^{-3}$ day $^{-1}$, which were due to the combination of a fluidized sand filter and a screen filter and relatively high ammonia loading rates of 1,138-1,339 $\mathrm{g}$ $\mathrm{m}^{-3}$ day $^{-1}$. However, the present results are comparable with those of Summerfelt and Sharrer (2004), Pfeiffer and Malone (2006), and Summerfelt (2006). Summerfelt and Sharrer (2004) found that the volumetric ammonia removal rate was
$101.1 \mathrm{~g} \mathrm{~m}^{-3}$ day $^{-1}$ with an ammonia loading rate of $140.6 \mathrm{~g}$ $\mathrm{m}^{-3}$ day $^{-1}$. Additionally, the volumetric TAN removal rates of Pfeiffer and Malone (2006) were 23.1-117.4 $\mathrm{g} \mathrm{m}^{-3}$ day $^{-1}$ with ammonia loading rates of $27-135 \mathrm{~g} \mathrm{~m}^{-3} \mathrm{day}^{-1}$. TAN removal rates of Summerfelt (2006) were 140.0-160.0 $\mathrm{g} \mathrm{m}^{-3} \mathrm{day}^{-1}$ when using Mapleton sand with ammonia loading rates of 131 . 5-165.9 $\mathrm{g} \mathrm{m}^{-3}$ day $^{-1}$ and were $170.0 \mathrm{~g} \mathrm{~m}^{-3}$ day $^{-1}$ when using Richmond Dale sand with ammonia loading rates of 205.3$322.3 \mathrm{~g} \mathrm{~m}^{-3}$ day $^{-1}$.

The TAN volumetric removal rates in PF of the present study were $35.0-310.5 \mathrm{~g} \mathrm{~m}^{-3}$ day $^{-1}$ with ammonia loading rates of $5-50 \mathrm{~g} \mathrm{~m}^{-3}$ day $^{-1}$. These results are lower than those of the two other studies. Greiner and Timmons (1998) reported that TAN removal rates by polystyrene were $84.0-480.0 \mathrm{~g} \mathrm{~m}^{-3}$ day${ }^{1}$ in high density tilapia culture $\left(168 \mathrm{~kg} / \mathrm{m}^{3}\right)$. Timmons et al. (2006) also reported that the TAN removal rate of polystyrene beads was $1,200 \mathrm{~g} \mathrm{~m}^{-3}$ day $^{-1}$ with an ammonia loading rate of $1,560 \mathrm{~g} \mathrm{~m}^{-3}$ day $^{-1}$. These differences may be due to differences in the operating characteristics of the biofilter media such as flow rate, temperature, and water quality parameters.

TAN volumetric removal rates in KF of the present study (32.1-288.1 $\mathrm{g} \mathrm{m}^{-3}$ day $^{-1}$ ) were higher than those in the studies of Lekang and Kleppe (2000), who used Norton rings and Finturf and Kaldnes filters $\left(22.0,56.8\right.$, and $60.0 \mathrm{~g} \mathrm{~m}^{-3}$ day $^{-1}$, respectively). These differences might be due to differences in the SSA and ammonia loading rate. The SSAs of Norton rings and Finturf media were 220 and $284 \mathrm{~m}^{2} / \mathrm{m}^{3}$, respectively, compared to $500 \mathrm{~m}^{2} / \mathrm{m}^{3}$ for $\mathrm{KF}$ in the present study. Lekang and Kleppe (2000) also used a lower ammonia loading rate $\left(1.5 \mathrm{~g} \mathrm{~m}^{-3}\right.$ day $\left.^{-1}\right)$ than that used in the present study $\left(5-50 \mathrm{~g} \mathrm{~m}^{-3}\right.$ day $\left.^{-1}\right)$. The volumetric removal rate by KF in the present study was also higher than that in a study by Ridha and Cruz (2001), who used polyethylene blocks $\left(8.9 \mathrm{~g} \mathrm{~m}^{-3}\right.$ day $\left.^{-1}\right)$ and polypropylene plastic chips $\left(9.3 \mathrm{~g} \mathrm{~m}^{-3}\right.$ day $\left.^{-1}\right)$, as both media also have a lower SSA $\left(200 \mathrm{~m}^{2} / \mathrm{m}^{3}\right)$ than that of Kaldnes and were treated with a lower ammonia loading rate $\left(10.3 \mathrm{~g} \mathrm{~m}^{-3}\right.$ day $\left.^{-1}\right)$. Compared with the results of Al-Hafedz et al. (2003), who used plastic rolls, PVC pipes, and scrub pads $(3.46,2.95$, and $3.2 \mathrm{~g}$ $\mathrm{m}^{-3}$ day $^{-1}$, respectively), the removal rate by KF in the present study showed higher performance, considering that the previous study used a lower ammonia loading rate $\left(11.8 \mathrm{~g} \mathrm{~m}^{-3}\right.$ day $\left.^{-1}\right)$ than that in the present study.

SF showed the lowest TAN removal rate based on area $(P$ $<0.05)$, whereas KF showed the highest TAN removal rate at all ammonia loading rates of 5, 25, and $50 \mathrm{~g} \mathrm{~m}^{-3}$ day $^{-1}$. The lowest value was observed in SF and was attributed to the high SSA of SF.

$\mathrm{NO}_{2}-\mathrm{N}$ concentrations in all biofilter systems were maintained under the limit $(<1 \mathrm{mg} / \mathrm{L})$, indicating that the three biofilters performed well to maintain water quality. SF always showed a higher $\mathrm{NO}_{2}-\mathrm{N}$ volumetric removal rate than that of the other media. KF showed the lowest removal rate and PF was in the middle. This result was also related with the SSAs of the biofilter media; the SSA of SF was higher than those of 
$\mathrm{PF}$ and KF.

The highest $\mathrm{NO}_{3}-\mathrm{N}$ concentrations in $\mathrm{SF}, \mathrm{PF}$, and $\mathrm{KF}$ were 284.3, 280.9, and $205.3 \mathrm{mg} / \mathrm{L}$, respectively, and these were still under the $>300 \mathrm{mg} / \mathrm{L}$ limit suggested by Masser et al. (1999).

\section{Filter media economics}

Biofilter media preference depends on many factors such as surface area, durability, and cost. Low capital cost is an important factor to consider when establishing a recirculating system for fish culture (Al-Hafedh et al., 2003). The prices of $\mathrm{SF}, \mathrm{PF}$, and KF per cubic meter based on recent prices given by online sellers are approximately 150 US\$, 100 US\$, and 1500 US\$, respectively. Considering variations in SSA among these media, the cost for obtaining a $100 \mathrm{~m}^{2}$ surface area is approximately 2 US\$ for SF, 3 US\$ for PF, and 300 US\$ for KF. However, SF requires high energy requirements to fluidize the sand bed (Wheaton et al., 1994b; Summerfelt, 2006), which increases energy costs. Therefore, polystyrene microbeads are recommended due to their good ammonia removal performance, light weight, and high economy per surface area volume.

\section{Acknowledgments}

Partial funding of this study was provided by the Korea Ocean Research and Development Institute through project PE98593, PE98565 and PK07920.

\section{References}

Al-Hafedh YS, Alam A and Alam MA. 2003. Performance of plastic biofilter media with different configuration in a water recirculation system for the culture of Nile tilapia (Oreochromis niloticus). Aquac Eng 29, 139-154.

Eikebrokk B. 1990. Design and performance of the BIOFISH water recirculation system. Aquac Eng 9, 285-294.

Eikebrokk B and Ulgenes Y. 1998. Recirculation technologies in Norwegian aquaculture. In: Proceedings of the 2nd International Conference on Recirculating Aquaculture. Libey GS and Timmons MB, eds. Virginia Polytechnic Institute and State Universiy, Blacksburg, VA, US, pp. 129-137.

Greiner AD and Timmons MB. 1998. Evaluation of the nitrification rates of microbead and trickling filters in an intensive recirculating tilapia production facility. Aquac Eng 18, 189-200.

Kamstra A, van der Heul JW and Nijhof M. 1998. Performance and optimization of trickling filters on eel farms. Aquac Eng 17, 175-192.

Lekang OI and Kleppe H. 2000. Efficiency of nitrification in trickling filters using different filter media. Aquac Eng 21, 181-199.

Losordo TM, Masser MP and Rakocy J. 1998. Recirculating Aquaculture Tank Production Systems: An Overview of Critical Considerations. Southern Regional Aquaculture Center Publication No. 451. Southern Regional Aquaculture Center, Soneville, MS, US.

Malone RF and Beecher LE. 2000. Use of floating bead filters to recondition recirculating waters in warmwater aquaculture production systems. Aquac Eng 22, 57-73.

Malone RF and Pfeiffer TJ. 2006. Rating fixed film nitrifying biofilters used in recirculating aquaculture systems. Aquac Eng 34, 389-402.

Masser MP, Rakocy J and Losordo TM. 1999. Recirculating Aquaculture Tank Production Systems: Management of Recirculating Systems. Southern Regional Aquaculture Center Publication No. 452. Southern Regional Aquaculture Center, Soneville, MS, US.

Oh SY. 2001. Nitrogen loading rate of Nile Tilapia and nitrification rate of rotating biological contactor. Unpublished Ph.D. dissertation. Pukyong National University, Busan, KR.

Pfeiffer T and Malone RF. 2006. Nitrification performance of a propeller-washed bead clarifier supporting fluidized sand biofilter in a recirculating warmwater fish systems. Aquac Eng 34, 311-321.

Ridha MT and Cruz EM. 2001. Effect of biofilter media on water quality and biological performance of the Nile tilapia Oreochromis niloticus L. reared in a simple recirculating system. Aquac Eng 24, 157-166

Rogers GL and Klemetson SL. 1985. Ammonia removal in selected aquaculture water reuse biofilters. Aquac Eng 4, 135-154.

Rusten B, Eikebrokk B, Ulgenes Y and Lygren E. 2006. Design and operation of the Kaldnes moving bed biofilm reactors. Aquac Eng 34, 322-331.

Shnel N, Barak Y, Ezer T, Dafni Z and van Rijn J. 2002. Design and performance of a zero-discharge tilapia recirculating system. Aquac Eng 26, 191-203.

Summerfelt ST. 2006. Design and management of conventional fluidized-sand biofilters. Aquac Eng 34, 275-302.

Summerfelt ST and Sharrer MJ. 2004. Design implication of carbon dioxide production within biofilters contained in recirculating salmonid culture systems. Aquac Eng 32, 171-182.

Timmons MB, Holder JL and Ebeling JM. 2006. Application of microbead biological filters. Aquac Eng 34, 332-343.

Wheaton FW, Hochheimer JN, Kaiser GE, Malone RF, Krones MJ, Libey GS and Easter CC. 1994a. Nitrification filter principles. In: Aquaculture Water Reuse Systems: Engineering Design and Management. Development in Aquaculture and Fisheries Science. Vol. 27. Timmons MB and Losordo TM, eds. Elsevier, Amsterdam, NL, pp. 101-126.

Wheaton FW, Hochheimer JN, Kaiser GE, Malone RF, Krones MJ, Libey GS and Easter CC. 1994b. Nitrification filter design methods. In: Aquaculture Water Reuse Systems: Engineering Design and Management. Development in Aquaculture and Fisheries Science. Vol. 27. Timmons MB and Losordo TM, eds. Elsevier, Amsterdam, NL, pp. 127-171. 